\title{
GENETIC VARIATION AND POPULATION STRUCTURE IN THE HUMPBACK GROUPER, Cromileptes altivelis, TROUGHOUT ITS RANGE IN INDONESIAN WATERS ${ }^{*}$
}

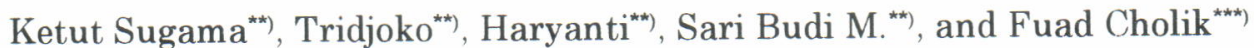

\begin{abstract}
Starch gel electrophoresis was used to assess the level and distribution of genetic variation in humpback grouper, Cromileptes altivelis sampled from 4 different areas of coral reefs in Raas and Kangean located in Madura as well as Sangeang and Bungin located in Sumbawa regions, between December 1997 and March 1998. Fifteen loci detected from eleven enzyme systems examined. Three loci: $A D H^{\star}, G P I^{*}$ and $I D H-1^{*}$ were polymorphic at $95 \%$ level. These three loci were in Hardy-Weinberg equilibrium at all samples and heterozygosities ranging from 0.058 to 0.089 with an average of 0.071 . No significant difference in allele frequencies between samples within region was detected, but significant differences were revealed between regions. The UPGMA cluster analysis of genetic distance showed that, the population of Madura region was clearly distinct from Sumbawa region and might not belong to one panmictic population.
\end{abstract}

KEYWORDS: Cromileptes altivelis, genetic variation, population structure.

\section{INTRODUCTION}

Groupers are popular marine food fish of high market value in many parts of the world including South East Asia, China, Taiwan, Japan, Australia, Mexico and Kuwait. Among these groupers, the humpback grouper, Cromileptes altivelis is the most expensive species (Pawiro, 1999)

In juvenile stage, (total length of $5-10 \mathrm{~cm}$ ), humpback grouper has a high demand for aquarium fish, and in adult size (body weight of 600$1300 \mathrm{~g}$ ) has high price and potential market in Hong Kong, Southern China and Taiwan. In Indonesia at present the price of juvenile grouper is US\$1.0/fish and in Singapore US\$ 3-7/fish, while bigger size and live fish is sold for US\$ $62-87 / \mathrm{Kg}$.

Most of the humpback grouper for both aquarium and consumption are caught from the wild. In some areas this species is rare as a result of over exploitation. Recently, Gondol Research Institute for Coastal Fisheries has successfully mass-produced the juveniles of humpback grouper. The seed production techniques of this species have been applied to backyard hatcheries. There is a growing interest in grouper culture using net cages and restocking in over-exploited area to develop an export industry in Indonesia (Sugama et al., 1999). Because of its economic importance, genetic variation and population structure of this fish need to be studied in more depth throughout its natural range. Several papers have emphasized on the important of maintaining the genetic variation in cultured stock of fish (Allendorf \& Phelps, 1980; Cross \& King, 1983; Kincaid, 1983; Taniguchi et al., 1983; Vuorinen, 1984; Sbordoni et al., 1986; Sugama et al., 1992). Loss of genetic variation in hatchery stocks of salmonid and penaeid shrimp have produced harmful effects on a variety of important traits such as fecundity, survival, growth rate, food conversion efficiency and body shape (Leary et al., 1985; Sbordoni et al., 1986). Furthermore, the loss of genetic variation may reduce the ability of fish to adapt to different environmental conditions. These problems are especial. ly important for hatchery bred juveniles, that are used in restocking programs (Ryman \& Sthal, 1980; Benzie, 1998).

Knowledge of the genetic structure of wild fish stocks will be vital for sound long-term management. If local strains exist, they are likely to be adapted to local conditions and will have better performance than imported stock. Significant genetic differentiation among population of marine fish has been noted in many studies (Taniguchi \& Sugama, 1990; Benzie et al., 1992; Ohtani et al., 1997; Foss et al., 1998; Castilho \& Mc.Andrew, 1998) but no published data on genetic variability and population genetic structure of humpback grouper is available so far.

\footnotetext{
*) Presented at theWorld Aquaculture Conference, Held in Sydney Australia April 25 - May 1, 1999

*) Researcher of the Research Station for Coastal Fisheries Gondol, Bali

**) Researcher of the Central Research Institute for Fisheries, Jakarta
} 
This study aimed to use allozyme electro. phoresis to described the genetic variability and genetic structure of humpback grouper population throughout its natural range. Data on genetic variation of this species may identify new sources of spawners for seed production in hatcheries.

\section{MATERIALS AND METHODS}

Wild population of humpback grouper, $C$. altivelis were collected from 4 areas (Sangeang and Bungin coral reefs in Sumbawa Island and Kangean and Raas coral reefs in Madura Island (East Jawa) (Figure1 and Table 1). The fish were transported alive to the Gondol Research Institute for Coastal Fisheries Laboratory. After dissection, tissue samples (muscle, liver, heart and eye) were stored at $-30^{\circ} \mathrm{C}$ until used.

Enzyme variation was assayed by horizontal starch gel electrophoresis (Taniguchi et al.,1983; Taniguchi \& Sugama, 1990). The list of enzymes examined, loci detected, buffer and tissue specificity are given in Table 2. Gels were prepared as $12 \%$ suspensions of hydrolyzed starch (Sigma S-4501). Gel electrode buffer used were Tris citric acid pH 8.0 (TC-8) and Citric acid aminopropyl morpholine pH 7 (CAMP-7) (Taniguchi \& Sugama, 1990).

Loci and alleles were scored by a nomenclature system as outlined by Shaklee et al. (1990). Loci were designated consecutive numbers with 1 denoting the fastest anodal migratory system.

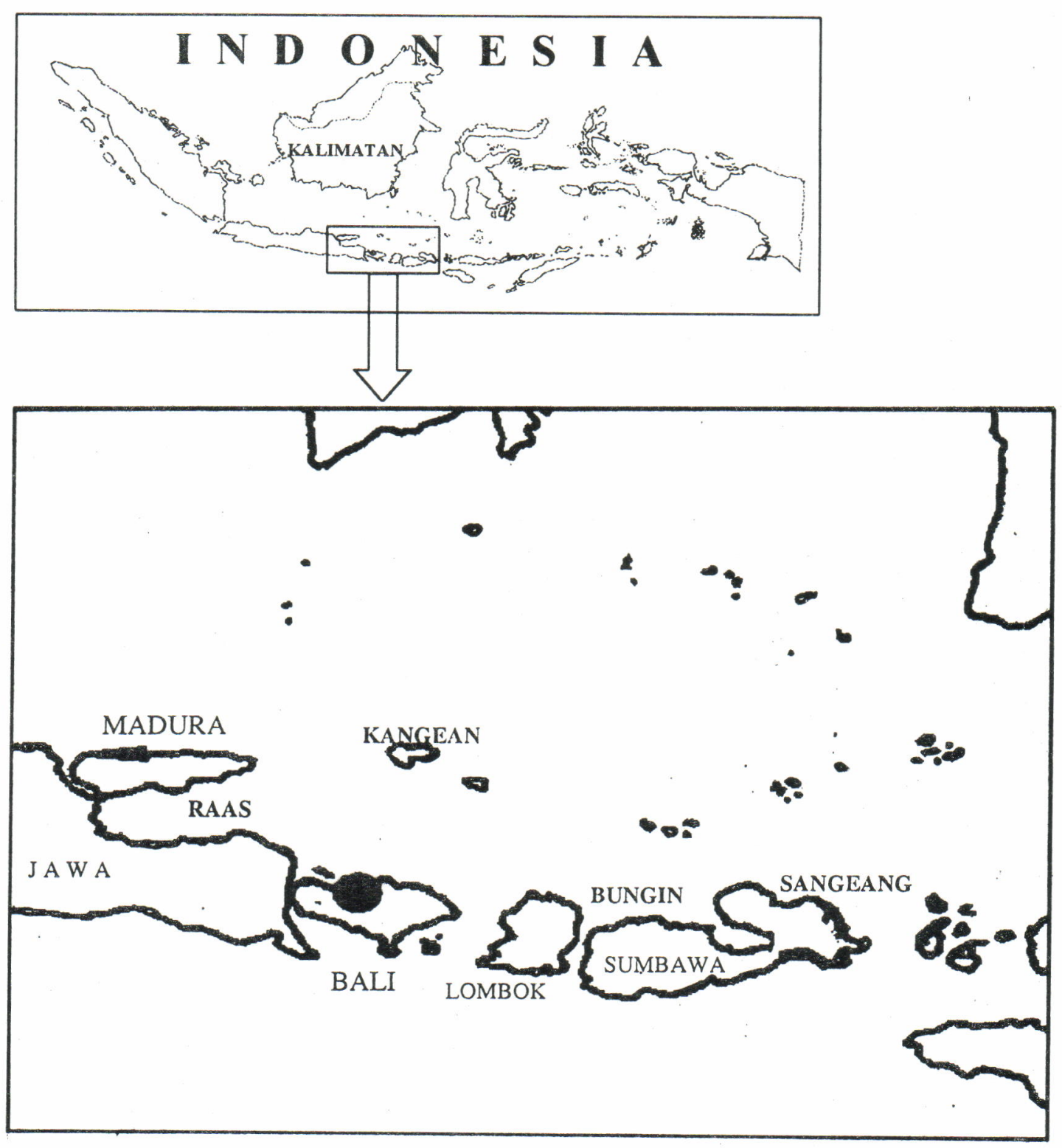

Figure 1. Sampling locations of humpback grouper, Cromileptes altivelis. 
Table 1. Source and number of humpback grouper, Cromileptes altivelis, analyzed genetically (see Fig. 1 for geographical location of sampling sites).

\begin{tabular}{llcc}
\hline \multicolumn{1}{c}{ Location } & $\begin{array}{c}\text { Sampling } \\
\text { date }\end{array}$ & $\begin{array}{c}\text { Sample size } \\
\text { (ind.) }\end{array}$ & $\begin{array}{c}\text { Range of BW } \\
\text { (g) }\end{array}$ \\
\hline - Sangeang & December'97 & 50 & $128.4 \cdot 248.0$ \\
- Bungin & January'98 & 60 & $173.5 \cdot 312.2$ \\
- Kangean & January'98 & 80 & $154.6 \cdot 264.4$ \\
- Raas & March'98 & 40 & $213.3 \cdot 330.8$ \\
\hline
\end{tabular}

Allelic variations were designated according to their relative mobility. The most common allele is designated 100 and other alleles were given numbers that indicated their mobility relative to that of the common allele. Cathodal systems were designated in a similar way but were given negative signs.

Allele frequencies at each polymorphic locus were tested for homogeneity or heterogeneity between locations with $\mathrm{c}^{2}$ test or G-test (Sokal \& Rohlf, 1981). Genetic relatedness among localities were estimated by Nei's (1972) genetic distance values was constructed using the UPGMA method of Sneath \& Sokal (1973). BIOSYS-1 (Swofford \& Selander, 1981) was used to confirm genotypic frequencies to Hardy-Weinberg equilibrium as well as average heterozygosities.

\section{RESULTS}

A survey of 11 enzyme systems has produced 15 consistently scorable loci (Table 2) of these $A D H^{*}, G P I^{*}$ and $I D H^{*}$ were polymorphic $\left(P_{0.95}\right)$ (Table 3). The remaining 12 putative loci showed no detectable variation. The electrophoretic banding pattern of 3 polymorphic loci was presented in Figure 2. The percentage of polymorphic loci using

Table 2. List of enzymes examined, locus detected, tissue and buffer specificity in humpback grouper, Cromileptes altivelis.

\begin{tabular}{|c|c|c|c|}
\hline Enzymes & Locus & Tissue $^{1}$ & Buffer $^{2}$ \\
\hline Aspartate dehydrogenase & $A A T^{*}$ & $\mathrm{~L}$ & $\mathrm{TC}-8$ \\
\hline Alcohol dehydrogenase & $A D H^{*}$ & $\mathrm{~L}$ & TC-8 \\
\hline Esterase & $E S T^{*}$ & $\mathrm{~L}$ & CAMP.7 \\
\hline Glucosephosphate isomerase & $G P I^{*}$ & $\mathrm{M}, \mathrm{L}$ & CAMP-7 \\
\hline$\alpha$-Glycerophosphate dehydrogenase & $\alpha-\left(G P D^{*}\right.$ & $\mathrm{M}$ & CAMP-7 \\
\hline \multirow[t]{2}{*}{ Isocitrate dehydrogenase } & $I D H-1^{*}$ & $\mathrm{M}, \mathrm{L}$ & CAMP-7 \\
\hline & II) $H-2^{*}$ & $\mathrm{M}, \mathrm{L}$ & CAMP-7 \\
\hline \multirow[t]{2}{*}{ Lactate dehydrogenase } & $L D H-1^{*}$ & $\mathrm{M}, \mathrm{E}$ & CAMP-7 \\
\hline & $L D H \cdot 2^{*}$ & $\mathrm{M}, \mathrm{E}$ & CAMP-7 \\
\hline \multirow[t]{3}{*}{ Malate dehydrogenase } & $M D H-1^{*}$ & $\mathrm{M}, \mathrm{L}, \mathrm{H}$ & CAMP-7 \\
\hline & $M I H \cdot 2^{*}$ & $\mathrm{M}, \mathrm{L}, \mathrm{H}$ & \\
\hline & $M D H-3^{*}$ & $\mathrm{M}, \mathrm{L}, \mathrm{H}$ & \\
\hline Malic enzyme & $M E^{*}$ & M & CAMP-7 \\
\hline 6-Phosphogluconate dehydrogenase & $6-P G D^{*}$ & $\mathrm{~L}, \mathrm{H}$ & CAMP-7 \\
\hline Phosphoglucomutase & $P\left(G M^{*}\right.$ & $\mathrm{M}, \mathrm{L}$ & CAMP-7 \\
\hline
\end{tabular}

1. $M=$ Muscle $L=$ Liver $;=$ Heart $E=$ Eye

2. TC-8=Tris-Citric Acid Buffer $p H$ 8; CAMP-7=Citric Acid-aminopropyl Morpholine

Buffer $p H 7$. 
Table 3. Allele frequencies, heterozygosities $(H$.$) and number of allele per locus (N a$.) at polymorphic loci in humpback grouper, Cromileptes altivelis, $\mathrm{N}=$ number of individual examined. See Figure 1 for locations.

\begin{tabular}{cccccc}
\hline \multirow{2}{*}{ Locus } & Alleles & \multicolumn{5}{c}{ Location } \\
\cline { 3 - 6 } & & $\begin{array}{c}\text { Sangeang } \\
\mathbf{( N = 5 0 )}\end{array}$ & $\begin{array}{c}\text { Bungin } \\
\mathbf{( N = 6 0 )}\end{array}$ & $\begin{array}{c}\text { Kangean } \\
\mathbf{( N = 8 0 )}\end{array}$ & $\begin{array}{c}\text { Raas } \\
\mathbf{( N = 4 0 )}\end{array}$ \\
\hline & & & & & \\
$A D H^{*}$ & -75 & 0.300 & 0.150 & 0.150 & 0.150 \\
& -100 & 0.660 & 0.767 & 0.850 & 0.850 \\
& -125 & 0.040 & 0.083 & 0.000 & 0.000 \\
$G P I^{*}$ & 100 & 0.530 & 0.550 & 0.575 & 0.525 \\
& 70 & 0.470 & 0.450 & 0.425 & 0.475 \\
$I D H-1^{*}$ & 100 & 0.780 & 0.800 & 0.919 & 0.937 \\
& 80 & 0.220 & 0.200 & 0.081 & 0.063 \\
$H^{1}$ & & 0.089 & 0.077 & 0.059 & 0.058 \\
$N a^{2}$ & & 1.267 & 1.267 & 1.200 & 1.200 \\
\hline
\end{tabular}

${ }^{1} \mathrm{H} .=$ Average observed heterozygosity over 15 loci

${ }^{2} \mathrm{Na}$. $=$ Average number of alleles per locus over 15 loci

$P_{0.95}$ criteria was $20.0 \%$, average heterozygosities among samples ranged from 0.058 (Raas, Madura) to 0.089 (Sangeang, Sumbawa) and number of allele per locus ranged from 1.200 (Kangean, Madura) to 1.267 (Bungin, Sumbawa). No significant deviation from Hardy-Weinberg expectations was observed in any sample.

Testings for heterogeneity $\left(c^{2}\right)$ of all possible pairwise comparisons of localities for main alleles at each locus were conducted. Of the 18 comparisons (3 loci x 6 pair wise comparisons), six were statistically significant (Table 4). The significantly different loci were $A D H-100^{*}$, between Sangeang-
Kangean $\left(\mathrm{c}^{2}{ }_{\mathrm{df}=1}=12.82, \mathrm{p}<0.01\right)$ and SangeangMadura $\left(\mathrm{c}_{\mathrm{df}=1}^{2}=8.43, \mathrm{p}<0.01\right)$, and ID H-1 100* between Sangeang-Kangean $\quad\left(c_{d f=1}^{2}=10.21\right.$, $\mathrm{p}<0.01)$, Sangeang-Raas $\left(\mathrm{c}^{2}{ }_{\mathrm{df}=1}=8.59, \mathrm{p}<0.01\right)$, Bungin-Kangean $\left(c_{d f=1}^{2}=8.47, p<0.01\right)$ and Bungin-Raas $\left(\mathrm{c}^{2}{ }_{\mathrm{df}=1}=7.26, \mathrm{p}<0.01\right)$. There were no significant differences between Sangeang and Bungin and between Kangean and Raas samples at any locus.

Genetic distance values (Nei, 1972) ranged from 0.0002 between Kangean-Raas to 0.0044 between Sangeang-Raas (Table 5).

Table 4. Chi-Square $\left(\mathrm{c}^{2}\right)$ values of heterogeneity test of each polymorphic locus between locations of humpback grouper, Cromileptes altivelis. (See Figure 1 for locations).

\begin{tabular}{lcccc}
\hline \multirow{2}{*}{ Location } & \multicolumn{4}{c}{ Locus, Allele } \\
\cline { 2 - 5 } & d.f. & $\boldsymbol{A D H}-\mathbf{1 0 0 *}$ & $\boldsymbol{G P I - 1 0 0 *}$ & $\boldsymbol{I D H}-\mathbf{1 - 1 0 0 *}$ \\
\hline Sangeang-Bungin & 1 & 3.09 & 0.09 & 0.13 \\
Sangeang-Kangean & 1 & $12.82^{* *}$ & 0.51 & $10.21^{* *}$ \\
Sangeang-Raas & 1 & $8.43^{* *}$ & 0.00 & $8.59^{* *}$ \\
Bungin-Kangean & 1 & 3.12 & 0.17 & $8.47^{* *}$ \\
Bungin-Raas & 1 & 2.07 & 0.12 & $7.26^{* *}$ \\
Kangean-Raas & 1 & 0.00 & 0.54 & 0.25 \\
\hline
\end{tabular}

${ }^{* *} \mathrm{p}<0.01$ 
Allele

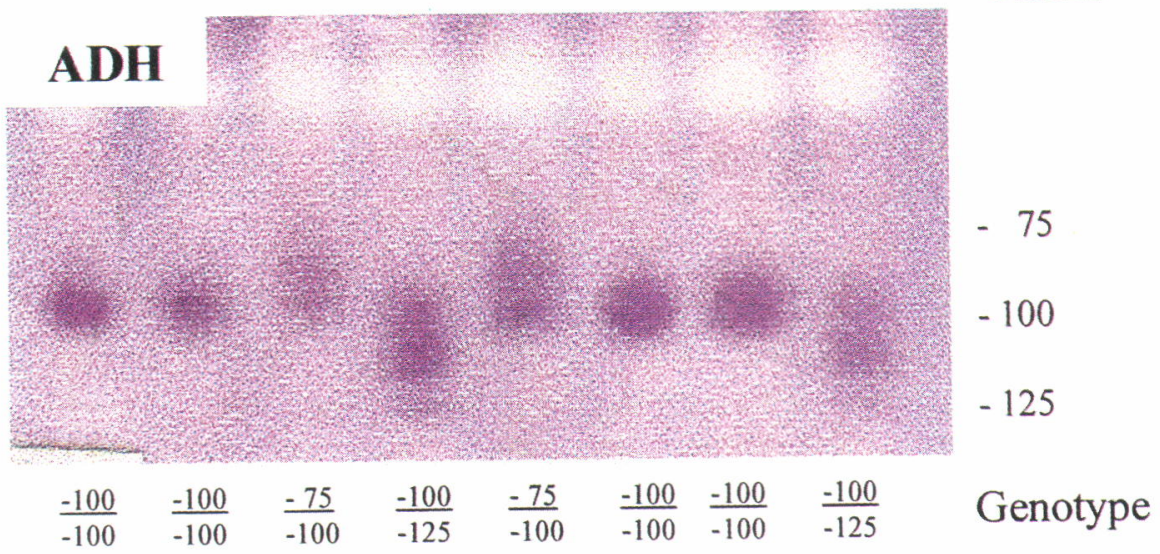

GPI

100

70

$\begin{array}{llllllllll}\frac{100}{100} & \frac{70}{70} & \frac{100}{70} & \frac{100}{70} & \frac{100}{100} & \frac{100}{70} & \frac{100}{100} & \frac{70}{70} & \frac{100}{100} & \frac{100}{100}\end{array} \quad$ Genotype

\section{IDH-1}

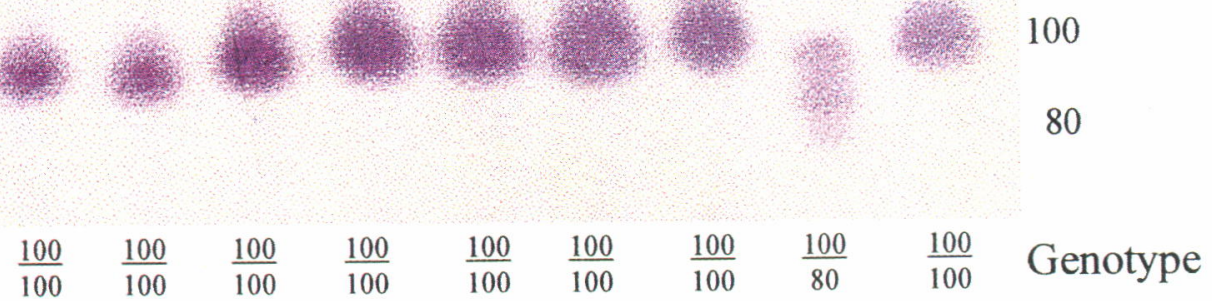

Figure 2. Electrophoretic banding pattern of polymorphic loci $\left(A D H^{*}, G P I^{*}\right.$ and $\left.I D H-1^{*}\right)$ in humpback grouper, Cromileptes altivelis. 
Table 5. Nei's (1972) genetic distances between humpback grouper, Cromileptes altivelis populations, based on 15 loci examined. (See Figure 1 for locations).

\begin{tabular}{lcccc}
\hline \multicolumn{1}{c}{ Location } & Sangeang & Bungin & Kangean & Madura \\
\hline Sangeang & - & & & \\
Bungin & 0.0016 & - & & \\
Kangean & 0.0041 & 0.0017 & - & \\
Raas & 0.0044 & 0.0021 & 0.0002 & - \\
\hline
\end{tabular}

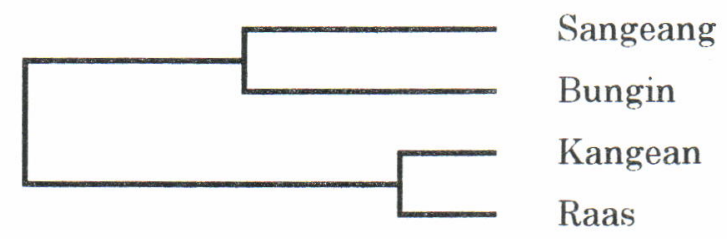

$\begin{array}{lllll}0.004 & 0.003 & 0.002 & 0.001 & 0.000\end{array}$

\section{GENETIC DISTANCE}

Figure 3. Cluster dendrogram (UPGMA) summarising the genetic relationship among four populations of the humpback grouper, Cromileptes altivelis based on their genetic distance as shown in Table 5.

The dendrogram constructed from the matrix of pairwise genetic distance values (UPGMA) revealed two groups: (I) Sangeang and Bungin (Sumbawa group) and (II) Kangean and Raas (Madura group) (Figure 3).

\section{DISCUSSION}

The levels of genetic variation observed in humpback grouper were comparable to those reported for 82 fish by Winans (1980). The genetic distance summation over 15 loci, revealed two genetically distinct populations of humpback grouper throughout its range. One was the coral reefs of Madura Island and the other one was along the coral reef of Sumbawa Island (Figure 1 and 3). Samples collected from coral reef areas of Sangeang and Bungin as well as Kangean and Raas showed similar allele frequencies over three polymorphic loci $\left(A D H^{*}, G P I^{*}\right.$ and $I D H-1^{*}$, Table 3 ). Heterogeneity test of pooled allele frequencies representing the two major coral reef group (Sumbawa and Madura areas) revealed evidence of allele frequencies differentiation at $\left(A D H 100^{*}\right.$ $\left(\mathrm{c}_{\mathrm{df}=1}^{2}=9.31, \mathrm{p}<0.01\right)$ and $I D H-1100^{*}\left(\mathrm{c}_{\mathrm{df}=1}^{2}=8.17\right.$, $\mathrm{p}<0.01)$. Because of the sharply discontinuous distribution of suitable humpback grouper habitat in the present study separated by distance of 250 $\mathrm{km}$, and the limited mobility of the territorial adults and the relatively brief pelagic larval stage, it was assumed that the lifecycle of humpback grouper inhibited significant levels of sub-population differentiation throughout the $250 \mathrm{~km}$ length of sampling area. This expectation is supported by the report of population sub-division for many other marine fish including Damselfish (Shaklee, 1984), Australian bass (Jerry, 1997) and Japanese sea bass (Ohtani et al., 1997).

There are two possible explanations for the genetic differences found between the coral reefs of Madura and Sumbawa areas. One possibility is that this coral reef represents the separate breeding stock maintained through active homing of larvae to the site of their spawning. This explanation seems highly improbable because of the high degree of local current variability and the lack of evidence that fish larvae can actively maintain their position rather than being passively transported by currents. The second explanation for the observed genetic differences is that the habitat into which an individual humpback 
grouper settled is genetically determined. From the management point of view, the Madura and Sumbawa humpback groupers should clearly be treated as separate stocks.

\section{REFERENCES}

Allendorf, F.W. and Phelps, S.R. 1980. Loss of genetic variation in a hatchery stock of cut throat trout. Trans. Am. Fish. Soc. 109: 537-543.

Benzie, J.A.H. 1998. Genetic structure of marine organisms and se Asian biogeography. In: Hall, R. and Holloway, J.D. (Eds.). Biogeography and Geological Evolution of SE Asian, Backbuys Publishers. Leiden. The Netherland. p. 197-209.

Benzie, J.A.H., Fusher, S. and Ballment, B. 1992. Geographical variation in allozyme frequencies of populations of Penaeus monodon, (Crustacea, Decapoda) in Australia. Austr. J. Mar. Freshwater Res. 43: 715-725.

Castilho, R. and Mc Andrew, B.J. 1998. Population structure of sea bass in Portugal: Evidence from allozyme. J. Fish Biol. 53: 1038-1049.

Cross, T.F. and King, J., 1983, Genetic effect of hatchery rearing in Atlantic salmon. Aquaculture 33: 33-40.

Foss, A., Imsland, A.K. and Nevdal, G. 1998. Population genetic studies of Atlantic halibut in the North Atlantic Ocean. J. Fish. Biol. 53: 901-905.

Jerry D.R. 1997. Population genetic structure of catadromous Australian bass from throughout its range. J. Fish. Biol. 51:909-920.

Kincaid, H.L. 1983. Inbreeding in fish population used for aquaculture. Aquaculture 33: 215-227.

Leary, F.L., Allendorf, F.W. and Knudsen, K.L. 1985. Developmental instability as an indicator of reduced genetic variation in hatchery trout. Trans. Am. Fish. Soc. 114: 230-235.

Nei, M. 1972. Genetic distance between population. American Naturalist 106: 283-292.

Pawiro, S. 1999. Trend in major Asian market for live grouper. APEC-NACA Workshop on Grouper Research and Development. 7-9 April 1999, HatYai. Thailand. 9 pp.

Ohtani, T., Miyahara, K. and Shimamoto, N. 1997. Genetic variability of allozymes in Japanese Sea Bass Lateolabrax japonicus in the coastal water of Hyogo Prefecture. Fish. Sci. 63: 175-178.

Ryman, N. and Stahl, G. 1980. Genetic change in hatchery stock s of brown trout (Salmo trutta). Can. J. Fish. Aquat. Sci. 37: 82-87.
Sbordoni, V., DeMatthaeis, E., Sbordoni, M.C., La Rosa, (.. and Mattoccia, O.O. 1986. Bottle neck effect and the depression of genetic variability in hatchery stock of Penaeus japonicus (Crustacea Decapoda). Aquaculture 57: 239-251.

Shaklee, J.B. 1984. Genetic variation and population structure in the damselfish, Stegates fasciolatus, throughout the Hawaian Archipelago. Copeia 3: 629-640

Shaklee, J.B., Allendorf, F.W., Marizot, D.C. and Whitt, G.S. 1990. Gene nomenclature for protein coding-loci in fish. Trans. Am. Fish. Soc. 119: 215 .

Sneath, P.H. and Sokal, R.R. 1973. Numerical Taxonomy. Freeman and Co. San Francisco, California. $859 \mathrm{pp}$.

Sokal, R.R. and Rohlf, R.G. 1981. Biometry. Freeman and Co. San Francisco. California. 776 pp.

Sugama, K., Trijoko, Wardoyo, Kumagai, S., and Matsuda, H. 1999. Natural spawning and larval rearing of barramundi cod Cromileptes altivelis. Paper presented at the Fifth Asian Fisheries Forum Chiang Mai Thailand. 12 pp.

Sugama, K., Taniguchi, N., and Singgo, S. 1992. Survival, growth and gonad development of triploid red sea bream, Pagrus major (Temminck et Schelegel): Use of allozyme markers for ploidy and family identification. Aqua. Fish. Manag. 23: 149159.

Swofford, D.L. and Selander, R.K. 1981. BIOSYS : A Computer Program for the Analysis of Allelic Variation in Population Genetic and Ssystematics. Release 1.7 Illinois. University of Illinois.

Taniguchi, N., Sumantadinata, K., and Iyama, S. 1983. Genetic change in the fisrt and second generation of hatchery stock of black sea bream. Aquaculture 35: 309-320.

Taniguchi, N. and Sugama, K. 1990. Genetic variation and population structure of red sea bream in the coastal water of Japan and in the South China Sea. Nippon Suisan Gakkaishi 56: 1069-1077.

Vuorinen, J. 1984. Reduction of genetic variability in a hatchery stock of brown trout, Salmo trutta L. J. Fish. Biol. 24: 339-348.

Winans, G.A. 1980. Geographic variation in the milkfish (Chanos chanos). I. Biochemical evidence. Evolution 27: 192-204. 